\title{
ANALISIS MANAJEMEN HOTEL SYARIAH YASMIN HOTEL AND RESTAURANT DI KABUPATEN BANGKA BARAT (TINJAUAN FATWA DSN MUI NO: 108/DSN-MUI/X/2016)
}

\author{
Mandala Faldini \\ IAIN Syaikh Abdurrahman Siddik Bangka Belitung
}

Abstract

This study aims to determine the implementation of Yasmin and Restaurant management in accordance with the National Sharia Council (DSN) Indonesian Ulema Council (MUI) Fatwa No. 108 / DSN-MUI / X / 2016 concerning Islamic hotels. This research is a qualitative research with a descriptive exploratory approach. The method used is an in-depth interview with the Manager of the Yasmin Hotel and Restaurant, accompanied by observation and documentation. The data analysis technique used is the James Spardley model of data analysis techniques through four stages, namely: Domain Analysis, Taxonomic Analysis, Componential Analysis, Cultural Theme Analysis. The results of this study indicate that the implementation of Yasmin hotel and restaurant management in West Bangka Regency is in accordance with the MUI DSN fatwa No: 108 / DSN-MUI / X/2016.

Keywords: Sharia hotel, Management, DSN fatwa

\section{Pendahuluan}

Indonesia merupakan negara yang mayoritas penduduknya beragama Islam. Data di Badan Pusat Statistik dan Kementerian Agama Republik Indonesia menunjukkan jumlah penduduk Indonesia yang menganut agama 
Islam sejumlah 207.176.162 juta jiwa penganut muslim dari jumlah total penduduk Negara Indonesia sebesar 237.641.326 juta jiwa. Berkisar sekitar $87,21 \%$ dari jumlah penduduk di Indonesia. ${ }^{1}$

Meningkatnya tren kesadaran muslim di Indonesia saat ini terhadap halal life style membuat kebutuhan akan berbagai macam produk dan aktivitas sesuai syariah meningkat. Berbagai macam bisnis syariah, telah banyak dilakukan oleh para pebisnis makanan dan produk halal, farmasi dan medical care, fashion dan kosmetik. Berbagai macam bisnis syariah tersebut, saat ini banyak diminati pebisnis adalah perhotelan syariah karena penerapan syariah dalam bisnis perhotelan sangat menguntungkan. Saat ini bisnis syariah telah menjadi gaya hidup umat Islam. ${ }^{2}$ Salah satu produk berbasis syariah yang saat ini cukup berkembang adalah bisnis akomodasi dan perhotelan di Indonesia. Saat ini diperkirakan ada sekitar 50 sampai 100 hotel syariah yang berpotensi di seluruh Indonesia. ${ }^{3}$

Peningkatan penyedia hotel syariah di Indonesia memunculkan kekritisan bagi pemerhati syariah atau kaum akademisi. Pertanyaan yang dimunculkan adalah apakah hotel syariah yang bermunculan hanya sekedar menawarkan tren nama syariah atau memang benar-benar pelaksanaan manajemennya sesuai dengan syariah. Salah satu hotel yang menarik dikaji adalah Yasmin Hotel and Restaurant di Kabupaten Bangka Barat yang merupakan penginapan dengan konsep syariah yang bermitra dengan jaringan operator hotel yaitu Airy Rooms. Hotel ini berada di Jl. Depati Amir No. 07, Muntok, Kabupaten Bangka Barat. Hotel yang telah berdiri lebih dari lima

\footnotetext{
1 Diolah dari data online di website Badan Pusat Statistik. (https://pkub.kemenag.go.id/files/pkub/file/file/Data/zuqi1368036766.pdf)., Badan Pusat Statistik 2010. Penduduk Menurut Wilayah dan Agama yang Dianut. Badan Pusat Statistik [Online]. Data Sensus Tahun 2010 adalah sensus kependudukan terakhir yang dilakukan secara periode 10 tahun sekali.

2 Kementerian Pariwisata RI edisi 1. (2016). The Indonesia halal Lifestyle \& Bussines. Indonesia halal Lifestyle April 2016. Jakarta: PT Indonesia Halal Lifestyle., hlm 67

3 Sofyan, Riyanto. (2017). Bisnis Hotel Syariah Berkembang di Jakarta. Republika

[Online], Tersedia: m.republika.co.id/amp_version/mwji0w. [19 Maret 2017]., hlm.67
} 
tahun, atas inisiatif dari bapak Muhammad Nurudin hotel ini memiliki kapasitas 26 kamar yang sudah memenuhi konsep syariah akan tetapi hanya 2 kamar saja yang dikhususkan pada Airy Rooms Syariah.

Dewan Syariah Nasional (DSN) melalui Fatwa DSN Majelis Ulama Indonesia No. : 108/DSN-MUI/X/2016 tentang pedoman penyelenggaraan pariwisata berdasarkan prinsip syariah telah memberikan penjelasan bahwa usaha hotel syariah adalah penyediaan akomodasi berupa kamar-kamar di dalam suatu bangunan yang dapat dilengkapi dengan jasa pelayanan makan dan minum, kegiatan hiburan dan atau fasilitas lainnya secara harian dengan tujuan memperoleh keuntungan yang dijalankan sesuai dengan prinsip syariah. Dengan demikian Fatwa ini merupakan acuan bagi hotel syariah dalam proses manajemen hotel, termasuk di Hotel Yasmin dan Restauran Bangka Barat. Untuk itu, artikel ini bermaksud memaparkan bagaimana analisis manajemen hotel syariah apabila ditinjau dengan Fatwa DSN No. 108/DSN-MUI/X/2016.

\section{Metode Penelitian}

Penelitian ini merupakan penelitian kualitatif dengan pendekatan deskriptif eksploratif. Metode yang digunakan adalah wawancara mendalam (depth interview) kepada Manajer Yasmin dan Restoran di sertai observasi dan dokumentasi. Teknik analisa data yang digunakan yakni teknik analisis data model James Spardley melalui empat tahap, yaitu: Analisis Domain, Analisis Taksonomi, Analisis Komponensial, Analisis Tema Kultural

\section{Hasil Penelitian}

Pada dasarnya hotel syariah sama dengan hotel pada umumnya yaitu sebagai tempat penyedia jasa akomodasi dan penginapan bagi wisatawan 
Perbedaan pada hotel syariah adalah aspek produk, pelayanan, dana pengelolaan yang sesuai dengan syariat Islam. ${ }^{4}$

Menurut Fatwa Dewan Syariah Nasional Majelis Ulama Indonesia No:108/DSN- MUI/X/2016 tentang pedoman penyelenggaraan pariwisata berdasarkan prinsip syariah bahwa usaha hotel syariah adalah penyediaan akomodasi berupa kamar-kamar di dalam suatu bangunan yang dapat dilengkapi dengan jasa pelayanan makan dan minum, kegiatan hiburan dan atau fasilitas lainnya secara harian dengan tujuan memperoleh keuntungan yang dijalankan sesuai dengan prinsip syariah. ${ }^{5}$

\section{Manajemen Hotel Syariah}

Menurut Anwar Basmallah, menyatakan bahwa hotel syariah merupakan suatu jasa akomodasi yang beroperasi dan menganut prinsipprinsip pedoman ajaran Islam. Secara operasionalnya, pelayanan yang diberikan di hotel syariah tentunya hampir menyerupai hotel konvensional/non-syariah pada umumnya. Namun konsep hotel ini menyeimbangkan aspek-aspek spiritual Islam yang berlaku di dalam pengelolaan dan pengoperasiannya. 6 Dalam pandangan awam, hotel syariah kadang masih dianggap sebagai suatu bisnis usaha jasa yang hanya dikhususkan untuk pangsa pasar muslim. Padahal hotel syariah merupakan akomodasi yang juga beroperasi 24 jam dan terbuka untuk segala kalangan, baik masyarakat muslim maupun non-muslim. Adapun rambu-rambu syariah yang bersifat umum dalam menjalankan usaha ekonomi, termasuk usaha perhotelan, meliputi:

4 Kementerian Pariwisata RI edisi 1. (2016). The Indonesia halal Lifestyle $\mathcal{E}$ Bussines. Indonesia halal Lifestyle April 2016. Jakarta: PT Indonesia Halal Lifestyle., hlm 67

${ }^{5}$ DSN-MUI. (2016). Fatwa Dewan Syari'ah Nasional Nomor 108/DSN-MUI/X/2016 Tentang Pedoman Penyelenggaraan Pariwisata Berdasarkan Prinsip Syariah [Online]. Tersedia : www.dsnmui.or.id.

6 Basmallah, Anwar. (2011). Hadirnya Kemasan Syariah dalam Bisnis Perhotelan di Tanah Air. Binus Bussines Review Vol. 2 No. 2, November 2011. 
a. Tidak memproduksi, memperdagangkan, menyediakan, atau menyewakan produk atau jasa yang secara keseluruhan maupun sebagiannya dilarang dalam ketentuan syariah. Seperti dalam hal makanan, mengandung unsur babi, minuman beralkohol, perjudian, perzinaan, dan yang semacam itu.

b. Tidak mengandung unsur kezhaliman, kemungkaran, kemaksiatan maupun kesesatan yang terlarang dalam kaidah syariah, baik secara langsung maupun tidak langsung;

c. Tidak ada pula unsur penipuan, kecurangan, kebohongan, ketidakjelasan, resiko yang berlebihan dan membahayakan

d. Ada komitmen menyeluruh dan konsekuen dalam menjalankan perjanjian yang disepakati antar pihak-pihak terkait.

Menurut Widyarini, hotel syariah adalah hotel yang menerapkan syariah Islam ke dalam kegiatan operasional hotel. Kesyariahan hotel ditonjolkan oleh manajemen dengan memunculkan moto, logo, ornamen interior, fasilitas kamar, fasilitas hotel maupun seragam atau pakaian yang dikenakan para karyawan hotel. ${ }^{7}$

Fasilitas standar secara umum untuk hotel syariah pada dasarnya sama dengan fasilitas hotel konvensional, kamar, restoran, maupun fasilitas olahraga. Perbedaannya untuk beberapa kasus ada pemisahan antara lakilaki dengan perempuan, tidak ada diskotik, bar dan night club maupun panti pijat serta tidak menyediakan minuman beralkohol. Ciri khas hotel syariah yang membedakan dengan hotel konvensional secara logika nalar, berdasarkan syiar agama dan tuntunan dalam Al-Quran dan Hadis adalah sebagai berikut:

a) Wajib ada masjid atau mushola serta fasilitas untuk solat (sajadah dan mukena). Hal ini perlu ada sebagai konsekuensi logis untuk

7 Widyarini. (2013). Pengelolaan Hotel Syariah di Kabupaten Bangka Barat. EKBISI; Jurnal Ekonomi dan Bisnis Islam Vol. VIII, No. 1, Desember 2013, hlm. 3 
memberikan fasilitas solat berjamaah, baik untuk karyawan hotel maupun tamu hotel.

b) Tersedia petunjuk arah kiblat, sajadah dan Al-Quran dan informasi waktu solat (kalender yang mencantumkan waktu solat) di setiap kamar. Tamu hotel perlu mendapatkan fasilitas tersebut, karena mayoritas penghuninya adalah kaum muslim. Al Qur'an sangat diperlukan untuk membedakan dengan hotel yang berkiblat ke "barat" yang selalu menyediakan kitab "injil" di setiap laci atau meja kamar tidur. Akan lebih baik bila saluran televisi juga menyediakan saluran khusus yang acaranya berlandaskan kaidah Islam, seperti Moeslim Channel dan sejenisnya.

c) Di kamar mandi disediakan kran untuk wudlu, bila mungkin ada sekat pemisah dengan closet. Dengan adanya air melalui kran, akan memberikan kemudahan bagi tamu untuk melakukan wudlu sesuai tuntunan.

d) Wajib diperdengarkan kumandang adzan, sehingga semua tamu hotel bisa mendengarnya. Untuk sholat subuh dan Magrib melakukan sholat berjamaah; terutama untuk para karyawan hotel. Ada pemberitahuan untuk tamu waktu sholat berjamaah.

e) Disediakan kursi dan meja tamu di luar kamar tidur, untuk menerima tamu yang bukan muhrim. Jika kondisinya tidak memungkinkan menemui tamu dilakukan di lobby hotel.

f) Memiliki sertifikat halal dari MUI (Majelis Ulama Indonesia) khususnya yang berhubungan dengan restoran (produk dan proses) di dalam hotel.

g) Untuk urusan perbankan, hotel syariah sebaiknya menggunakan jasa perbankan syariah bila dimungkinkan. Di beberapa kota yang belum ada bank syariahnya, maka dengan terpaksa bisa digunakan jasa bank konvensional.

h) Tidak menempatkan ornamen, hiasan ataupun lukisan dari makhluk 
bernyawa di area luar dan dalam hotel.

i) Melarang tamu berlainan jenis dalam satu kamar, kecuali bisa dibuktikan suami- isteri atau kakak-beradik (muhrim)

j) Jika menyediakan tempat untuk berolah raga (kolam renang, fitness centre) agar dibedakan tempatnya untuk kaum laki-laki dan perempuan.

k) Karyawan menggunakan busana muslim yang sopan dan rapi.

I) Budaya salam dan senyum harus dilakukan oleh karyawan.

m) Hotel yang menawarkan jasa laundry harus melakukan proses pembersihan dari najis.

n) Musik yang dilantunkan cenderung pada musik-musik Islami (misal: kasidah, hadroh, marawis maupun irama padang pasir), untuk membentuk suasana islami.

\section{Dewan Syariah Nasional (DSN)}

a. Profil Dewan Syariah Nasional (DSN)

Dewan Syariah Nasional (DSN) adalah lembaga yang dibentuk oleh Majelis Ulama Indonesia (MUI) yang mempunyai fungsi melaksanakan tugas-tugas MUI dalam menangani masalah-masalah yang berhubungan dengan aktivitas lembaga keuangan syariah. Dewan Syariah Nasional (DSN) akan menampung berbagai masalah/kasus yang memerlukan fatwa agar diperoleh kesamaan dalam penanganannya dari masing-masing Dewan Pengawas Syariah yang ada di lembaga keuangan syariah. Adapun tugas, wewenang dan mekanisme kerja DSN sebagai berikut:

1) Tugas Dewan Syariah Nasional

a. Menumbuh-kembangkan penerapan nilai-nilai syariah dalam kegiatan perekonomian pada umumnya dan keuangan pada khususnya.

b. Mengeluarkan fatwa atas jenis-jenis kegiatan keuangan. 
c. Mengeluarkan fatwa atas produk dan jasa keuangan syariah.

d. Mengawasi penerapan fatwa yang telah dikeluarkan.

2) Wewenang Dewan Syariah Nasional

a. Mengeluarkan fatwa yang mengikat Dewan Pengawas Syariah di masing- masing lembaga keuangan syariah dan menjadi dasar tindakan hukum pihak terkait.

b. Mengeluarkan fatwa yang menjadi landasan bagi ketentuan/peraturan yang dikeluarkan oleh instansi yang berwenang, seperti Departemen Keuangan dan Bank Indonesia.

c. Memberikan rekomendasi dan/atau mencabut rekomendasi nama-nama yang akan duduk sebagai Dewan Pengawas Syariah pada suatu lembaga keuangan syariah.

d. Mengundang para ahli untuk menjelaskan suatu masalah yang diperlukan dalam pembahasan ekonomi syariah, termasuk otoritas moneter/lembaga keuangan dalam maupun luar negeri.

e. Memberikan peringatan kepada lembaga keuangan syariah untuk menghentikan penyimpangan dari fatwa yang telah dikeluarkan oleh Dewan Syariah Nasional.

f. Mengusulkan kepada instansi yang berwenang untuk mengambil tindakan apabila peringatan tidak diindahkan.

3) Mekanisme Kerja Dewan Syariah Nasional

a. Dewan Syariah Nasional mengesahkan rancangan fatwa yang diusulkan oleh Badan Pelaksana Harian DSN.

b. Dewan Syariah Nasional melakukan rapat pleno paling tidak satu kali dalam tiga bulan, atau bilamana diperlukan.

c. tahunnya membuat suatu pernyataan yang dimuat dalam laporan tahunan (annual report) bahwa lembaga keuangan syariah yang bersangkutan telah/tidak memenuhi segenap ketentuan syariah sesuai dengan fatwa yang dikeluarkan oleh Dewan Syariah 
Nasional

b. Fatwa DSN-MUI No:108/DSN-MUI/X/2016 tentang Pedoman Penyelenggaraan Pariwisata Berdasarkan Prinsip Syariah.

Usaha hotel syariah adalah penyediaan akomodasi berupa kamar-kamar di dalam suatu bangunan yang dapat dilengkapi dengan jasa pelayanan makan dan minum, kegiatan hiburan dan atau fasilitas lainnya secara harian dengan tujuan memperoleh keuntungan yang dijalankan sesuai dengan prinsip syariah.

Kriteria usaha hotel syariah adalah rumusan kualifikasi dan/atau klasifikasi yang mencakup aspek produk, pelayanan, dan pengelolaan. Ketentuan terkaithotel syariah yaitu :

1. Hotel syariah tidak boleh menyediakan fasilitas akses pornografi dan tindakan asusila

2. Hotel syariah tidak boleh menyediakan fasilitas hiburan yang mengarah kepada kemusyrikan, maksiat, pornografi, dan/atau tindak asusila

3. Makanan dan minuman yang disediakan hotel syariah wajib telah mendapatkan sertifikat halal dari MUI

4. Menyediakan fasilitas, peralatan dan sarana yang memadai untuk pelaksanaan ibadah, termasuk fasilitas bersuci

5. Pengelola dan karyawan/karyawati hotel wajib mengenakan pakaian yang sesuai dengan syariah.

6. Hotel syariah wajib memiliki pedoman dan/atau panduan mengenai prosedur pelayanan hotel guna menjamin terselenggaranya pelayanan hotel yang sesuai dengan prinsip syariah.

7. Hotel syariah wajib menggunakan jasa lembaga keuangan syariah dalam melakukan pelayanan. 


\section{Manajemen Hotel Yasmin dan Restaurant Kabupaten Bangka Barat}

a. Pengelolaan

Hotel Yasmin dan Restaurant dalam pengelolaannya menggunakan sistem dan teknologi yang modern sehingga membantu kinerja karyawan hotel dengan baik dan sesuai dengan pelayanan yang baik. Dalam pengelolaannya terhadap tamu menginap hotel, demi kemudahan dan kelancaran pelayanan tamu menginap, maka hotel Yasmin dan Restoran Kab. Bangka Barat menggunakan caption hospitality. Dengan caption membantu hampir semua lini pengelolaan hotel di hotel Yasmin dan Restoran Kabupaten Bangka Barat. Para staf telah menggunakan crono pos dalam pengelolaan hotel sehari-hari. Selain memudahkan proses reservasi, sistem hotel dari caption juga mempermudah proses check in dan check out tamu yang bisa dilakukan dengan sekali klik saja. Hal ini tentu memberikan pengaruh besar terhadap waktu pelayanan tamu dengan cepat dan efisien. Kemudian mempermudah para staf untuk mengelola pembayaran dari tamu dengan adanya menu payment pada sistemnya. Disisi lain sebagai alat bantu utama bagi staf manajerial dengan system yang didesain secara khusus untuk kebutuhan staf manajerial untuk pekerjaan mengelola hotel menjadi sangat mudah. Dengan demikian efisiensi kerja terjaga, administratif dalam pengelolaan tamu bisa dilakukan dengan lebih cepat dan efektif. Staf front desk dapat lebih cepat melayani tamu dengan resiko kesalahan input data yang lebih rendah. Hal ini sangat berpengaruh pada kinerja manajemen secara keseluruhan.

Dalam pengelolaan kinerja karyawan, hotel Yasmin dan Restoran Kabupaten Bangka Barat memperkerjakan 26 karyawan dengan jumlah karyawan 12 orang dan karyawati 14 orang pada hotelnya, dengan meminimalisir jumlah karyawan yang bekerja di hotel Yasmin dan Restoran Kabupaten Bangka Barat tersebut diharapkan pekerjaan akan maksimal dan 
saling tanggung jawab atas pekerjaannya dan mengurangi intensitas menganggur dalam bekerja. Hotel Yasmin dan Restoran Kabupaten Bangka Barat memperkerjakan karyawannya dengan rata-rata latar belakang karyawan yang pernah sekolah pariwisata. Hotel ini menerapkan sistem tiga kali shift yaitu shift pagi, siang, dan malam dengan jam bekerja 7 jam dan istirahat 1 jam. Hotel Yasmin dan Restoran Kabupaten Bangka Barat memberikan extra off kerja ketika hari-hari besar atau liburan dengan jumlah total 15 kali libur dalam kurun waktu setahun. Evaluasi kerja dilakukan setiap sebulan sekali untuk departemen housekeeping dan front office.

b. Pelayanan

Pelayanan yang segera dan cepat sangat sekali diutamakan bagi semua bisnis yang menawarkan jasa tak terkecuali hotel syariah. Hotel Yasmin dan Restoran telah menerapkan keutamaan pelanggan dengan merespon pelanggan secara cepat dan segera dalam melakukan reservasi hotel, pemesanan kamar hotel, dan komplain tamu menginap hotel. Dalam pelayanan reservasi hotel yang segera dan cepat, Hotel Yasmin dan Restoran Kabupaten Bangka Barat menyediakan whatsaap, facebook, instagram, website, dan nomor telepon hotel agar mempermudah tamu menginap hotel saat reservasi hotel sebelum pemesanan hotel terjadi. Pemesanan hotel sangat mudah karena Hotel Yasmin dan Restoran Kabupaten Bangka Barat bekerja sama dengan beberapa sistem pemesanan hotel online untuk mempermudah proses pembookingan hotel. Komplain pelanggan ditanggapi dengan cepat dan segera di follow up permasalahan yang ada dan ditangani dengan sebaik dan sebijak mungkin. Pelayanan yang ramah dan menunjukkan sikap yang sopan dan professional serta mencerminkan keislaman dengan adanya lagu atau musik yang diputar di runag tunggu hotel dengan musik yang bernuansa Islami. 
Pemesanan kamar hotel selain menggunakan aplikasi online atau alat bantu cepat dengan teknologi canggih, ketika kita akan melakukan check in, kita akan mengisi form terlebih dahulu dengan segala ketentuan dan peraturan yang ada di Hotel Yasmin dan Restoran Kabupaten Bangka Barat salah satunya adalah, jika tamu berpasangan diharuskan untuk menunjukkan $\mathrm{KTP} / \mathrm{KK} /$ foto pernikahan. Kemudian kita akan mendapatkan fasilitas wifi gratis dengan diberikan password wifi dan nomor telepon customer service jika ada hal yang dibutuhkan.

Hotel Yasmin dan Restoran Kabupaten Bangka Barat memiliki kapasitas 26 kamar dengan tipe dan harga kamar yang berbeda-beda. Demi memudahkan para tamu menginap, hotel Yasmin dan Restoran Kabupaten Bangka Barat tidak menyediakan lift dikarenakan hotel ini hanya memiliki tiga lantai. Fasilitas yang diberikan hotel sangat memuaskan dari mulai TV, bed, lemari, AC, meja rias, sajadah, arah kiblat, closet yang terpisah dengan kamar mandi, shower air panas dan dingin, tissue, handuk, sabun, sikat gigi dan pasta gigi, serta coffe break di pagi hari dan juga fasilitas pendukung seperti Free Wi Fi dan Free Rental Bike.

Demi kepuasan tamu hotel Yasmin dan Restoran Kabupaten Bangka Barat, bagian front office siap untuk menerima keluh kesah pelanggan, komplain pelanggan, saran dan masukan dari pelanggan hotel. Ketika ada ketidakpuasan tamu hotel terhadap harga kamar yang menurutnya tidak sesuai, maka hotel memberikan informasi harga pasar yang sesuai dengan tingkatan hotel bintang empat yang sama dengan Hotel Yasmin dan Restoran Kabupaten Bangka Barat. Pelayanan dan penawaran Pihak hotel Yasmin dan Restoran Kabupaten Bangka Barat biasanya akan memberikan informasi dan penawaran tentang informasi promo harga menginap hotel dengan berbagai macam tipe kamar, dan diberikan informasi up grade kamar dengan fasilitas terbaru di hotel Yasmin dan Restoran Kabupaten Bangka Barat akan diberikan kepada pelanggan yang sudah sering menggunakan jasa hotel ini. Hotel 
Yasmin dan Restoran juga memiliki Guest House, Laundry dan Yasmin Water serta Yasmin Buana wisata tour \& travel.

\section{Analisis Manajemen hotel Yasmin dan Restaurant menurut Fatwa No:108/DSN- MUI/X/2016}

Analisis manajemen hotel syariah Adilla menurut Fatwa DSN MUI No:108/DSN-MUI/X/2016 adalah sebagai berikut:

a. Produk

Menurut fatwa DSN MUI No:108/DSN-MUI/X/2016 mengenai aspek produk hotel syariah adalah:

1) Hotel syariah tidak boleh menyediakan fasilitas akses pornografi dan tindakan asusila

Penyediaan produk/jasa pada hotel syariah harus sesuai dengan yang dijanjikan dalam artian segala penawaran produk yang telah ada di hotel Yasmin dan Restoran Kabupaten Bangka Barat sesuai dengan adanya fasilitas tersebut. Informasi, iklan, promosi produk/jasa hotel Yasmin dan Restoran Kabupaten Bangka Barat yang telah terekspos pada media cetak, online, website dan lain-lain telah sesuai dengan realita produk hotel Yasmin dan Restoran Kabupaten Bangka Barat sehingga informasi yang sampai pada pelanggan dengan akurat dan benar.

Hotel Yasmin dan Restoran Kabupaten Bangka Barat berkonsep Islami dengan tujuan untuk memberikan kemudahan fasilitas menginap bagi keluarga, umat Islam dan masyarakat lainnya dengan pelayanan dan fasilitas yang halal. Adanya seleksi tamu menginap bagi tamu yang berpasangan dengan mengisi form registrasi dan menunjukkan $\mathrm{KTP} / \mathrm{KK} / \mathrm{Buku}$ nikah/foto pernikahan. Selain itu saluran televisi yang disajikan dalam fasilitas kamar telah dipilih oleh 
pihak hotel, sehingga tidak memuat saluran yang memuat konten pornografi.

2) Hotel syariah tidak boleh menyediakan fasilitas hiburan yang mengarah kepada kemusyrikan, maksiat, pornografi, dan/atau tindak asusila

Pada hotel Yasmin dan Restoran Kabupaten Bangka Barat, tidak menyediakan club malam atau hiburan malam serta tidak menyediakan minuman beralkohol, narkoba dan lain-lain dalam hotel. Hotel Yasmin memiliki 2 lantai, lantai bawah adalah mushola, tempat lobi, tempat resepsionis, dan restoran. Lantai 2 adalah kamarkamar yang disediakan pihak hotel untuk melayani tamu dan juga 1 ruang untuk meeting.

b. Pengelolaan

Menurut fatwa DSN MUI No:108/DSNMUI/X/2016 mengenai pengelolaan hotel syariah adalah:

1) Makanan dan minuman yang disediakan hotel syariah wajib telah mendapatkan sertifikat halal dari MUI.

Hotel Yasmin dan Restoran Kabupaten Bangka Barat sudah memiliki sertifikat halal MUI dikarenakan hotel Yasmin dan Restoran Kabupaten Bangka Barat sudah memiliki restaurant sendiri, dan pihak hotel memberikan jasa yang halal dengan menggunakan produk-produk makanan berlabel halal MUI serta proses pengolahan makanan yang halal. Proses pengawasan terhadap penyedia makanan dilaksanakan oleh pihak manajemen hotel secara berkala.

2) Pengelola dan karyawan/karyawati hotel wajib mengenakan pakaian yang sesuai dengan syariah.

Seluruh karyawan dan karyawati hotel Yasmin dan Restoran Kabupaten Bangka Barat menggunakan pakaian yang sesuai dengan 
syariah. Untuk pria sopan dan untuk wanita menggunakan pakaian tertutup rapi dan menggunakan kerudung.

3) Hotel syariah wajib memiliki pedoman dan/atau panduan mengenai prosedur pelayanan hotel guna menjamin terselenggaranya pelayanan hotel yang sesuai dengan prinsip syariah.

Hotel Yasmin dan Restoran Kabupaten Bangka Barat memiliki standar operasional dalam manajemen dan pengelolaan hotel secara umum, namun belum memiliki pedoman dan/atau panduan khusus mengenai prosedur pelayanan hotel guna menjamin terselenggaranya pelayanan hotel yang sesuai prinsip syariah. Hotel Yasmin dan Restoran Kabupaten Bangka Barat hanya menggunakan prinsip Islam yang telah diketahui masyarakat secara umum. Prosedur ini muncul secara terpisah di bagian penerima tamu, penyedia layanan kamar, dan bagian-bagian yang lain.

Prinsip Islami/syariah pada hotel Yasmin dan Restoran adalah dengan adanya wujud pelayanan dan fasilitas hotel seperti seleksi tamu menginap hotel bagi pasangan, tersedianya tempat beribadah, kemudahan untuk bersuci dan beribadah, tidak adanya hiburan malam, tidak tersedianya minuman beralkohol, narkoba dan lain sebagainya.

4) Hotel syariah wajib menggunakan jasa lembaga keuangan syariah dalam melakukan pelayanan

Pengelolaan keuangan pada hotel Yasmin dan Restoran belum menggunakan perbankan syariah dalam melakukan pelayanan maupun pengelolaan keuangan, dikarenakan pihak hotel masih mampu untuk mengelola keuangannya sendiri. Hotel ini mengelola keuangannya dengan pengelolaan internal saja. 
c. Pelayanan

Menurut fatwa DSN MUI No:108/DSN-MUI/X/2016 mengenai pelayanan hotel syariah adalah:

1) Hotel syariah tidak boleh menyediakan fasilitas akses pornografi dan tindakan asusila.

Hotel Yasmin dan Restoran Kabupaten Bangka Barat tidak menyediakan fasilitas akses pornografi. Adanya batasan terhadap konten-konten tertentu pada fasilitas wifi hotel berguna untuk mencegah akses pornografi dan tindakan asusila. Dalam hal ini, hotel Yasmin dan Restoran Kabupaten Bangka Barat dalam implementasinya sesuai dengan fatwa DSN No:108/DSNMUI/X/2016 perihal tidak diperbolehkannya menyediakan fasilitas akses pornografi dan tindakan asusila.

2) Hotel syariah tidak boleh menyediakan fasilitas hiburan yang mengarah kepada kemusyrikan, maksiat, pornografi, dan/atau tindak asusila.

Hotel Yasmin dan Restoran Kabupaten Bangka Barat tidak menyediakan fasilitas layanan kamar yang mengarah kepada kemusyrikan, maksiat, pornografi dan/atau tindak asusila. Serta dengan tidak adanya hiburan malam seperti club, karaoke dan lain sebagainya yang cenderung mengarah kepada kemusyrikan, maksiat, pornografi, dan/atau tindak asusila.

3) Menyediakan fasilitas, peralatan dan sarana yang memadai untuk pelaksanaan ibadah, termasuk fasilitas bersuci

Pelayanan hotel Yasmin Kabupaten Bangka Barat sangat memuaskan dan sesuai dengan konsep Islami. Dengan adanya mushola dalam hotel serta disediakannya arah kiblat dan mukena serta sajaddah di setiap kamarnya. Hotel Yasmin dan Restoran sendiri 
memisahkan antara kran wudhu dan juga shower mandi serta memisahkan antara closet dengan tempat wudhu.

\section{Kesimpulan}

Secara Umum Hotel Yasmin dan Restoran Kabupaten Bangka Barat sebagai salah satu jasa penyedia akomodasi perhotelan berbasis syariah telah sesuai dengan Fatwa DSN MUI No:108/DSN-MUI/X/2016 tentang pedoman penyelenggaraan pariwisata berdasarkan prinsip syariah. Hal ini dapat dilihat dalam uraian yang berkaitan dengan produk, pelayanan, dan pengelolaan. Akan tetapi ada beberapa hal yang masih perlu disempurnakan, antara lain berkaitan dengan pedoman dan/atau panduan mengenai prosedur pelayanan hotel guna menjamin terselenggaranya pelayanan hotel yang sesuai dengan prinsip syariah, perlunya jasa perbankan syariah dalam pelayanan. Peningkatan kedua hal tersebut merupakan upaya jaminan pihak manajemen Hotel Yasmin dan Restoran kepada masyarakat, bahwa pihak hotel selalu memastikan prinsip-prinsip syariah tetap menjadi landasan utama manajemen hotel. 


\section{DAFTAR PUSTAKA}

Badan Pusat Statistik 2010. Penduduk Menurut Wilayah dan Agama yang Dianut. Badan Pusat Statistik [Online]. Tersedia: www.bps.go.id.

Basmallah, Anwar. (2011). Hadirnya Kemasan Syariah dalam Bisnis Perhotelan di Tanah Air. Binus Bussines Review Vol. 2 No. 2, November 2011.

DSN-MUI. (2016). Fatwa Dewan Syari'ah Nasional Nomor 108/DSN-MUI/X/2016 Tentang Pedoman Penyelenggaraan Pariwisata Berdasarkan Prinsip Syariah [Online]. Tersedia : www.dsnmui.or.id.

Kementerian Pariwisata RI edisi 1. (2016). The Indonesia halal Lifestyle $\mathcal{E}$ Bussines. Indonesia halal Lifestyle April 2016 hlm 67. Jakarta: PT Indonesia Halal Lifestyle.

Komar, Rechard. (2014). Manajemen Hotel. Jakarta: Grasindo

Sofyan, Riyanto. (2017). Bisnis Hotel Syariah Berkembang di Jakarta. Republika [Online], Tersedia: m.republika.co.id/amp_version/mwji0w. [19 Maret 2017].

Sulastiyono, Agus. (2011). Manajemen Penyelenggaraan Hotel. Bandung: Alfabeta.

Widyarini. (2013). Pengelolaan Hotel Syariah di Kabupaten Bangka Barat. EKBISI; Jurnal Ekonomi dan Bisnis Islam Vol. VIII, No. 1, Desember 2013 